International Journal of Current Micro6iology and Applied Sciences

ISSN: 2319-7706 Volume 6 Number 7 (2017) pp. 488-493

Journal homepage: http://www.ijcmas.com

Original Research Article

https://doi.org/10.20546/ijcmas.2017.607.058

\title{
Nutrient Management in Mungbean [Vigna radiata (L.) Wilczek] for Higher Production and Productivity under Semi-arid Tract of Central India
}

\author{
Ghanshyam Verma $^{1}$, Narendra Kumawat ${ }^{2 *}$ and Jagdeesh Morya ${ }^{3}$ \\ ${ }^{1}$ Department of Seed Technology, Institute of Agricultural Sciences, \\ Bundelkhand University, Jhansi (U.P.), India \\ ${ }^{2}$ AICRP on Maize, Zonal Agricultural Research Station, Jhabua - 457661 (M.P.), India \\ ${ }^{3}$ Krishi Vigyan Kendra, Jhabua - 457661 (M.P.), India \\ *Corresponding author
}

\begin{tabular}{|c|c|}
\hline & A B S T R A C T \\
\hline $\begin{array}{l}\text { Ke y w o r d s } \\
\text { Nutrient } \\
\text { management, } \\
\text { Mungbean and } \\
\text { Semi-arid. }\end{array}$ & $\begin{array}{l}\text { A field experiment was carried out during kharif } 2013-14 \text { at Agriculture Research Farm, } \\
\text { Institute of Agricultural Sciences, Bundelkhand University, Jhansi, Uttar Pradesh to study } \\
\text { the effect of nutrition management on growth, yield attributes and yields of mungbean. } \\
\text { Results reveals that application of Rhizobium }+ \text { PSB }+20 \mathrm{~kg} \mathrm{~N} / \mathrm{ha} \text { gave significantly } \\
\text { higher number of nodules ( } 25.10 / \text { plant }) \text { and dry weight of nodules }(24.10 \mathrm{mg} / \mathrm{plant}) \text { which } \\
\text { was statistically at par with Rhizobium }+\mathrm{PSB}+60 \mathrm{~kg} \mathrm{P} \mathrm{P}_{5} / \mathrm{ha} \text {. Similarly maximum yield }\end{array}$ \\
\hline Article Info & 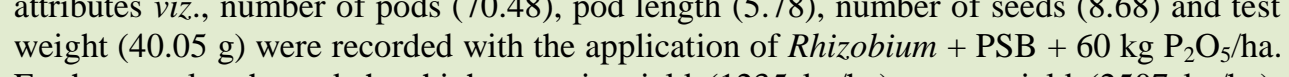 \\
\hline $\begin{array}{l}\text { Accepted: } \\
\text { 04 June } 2017 \\
\text { Available Online: } \\
\text { 10ss July } 2017\end{array}$ & $\begin{array}{l}\text { Further results showed that highest grain yield }(1235 \mathrm{~kg} / \mathrm{ha}) \text {, straw yield }(2507 \mathrm{~kg} / \mathrm{ha}) \text {, } \\
\text { harvest index }(33.0 \%) \text { and production efficiency }(17.39 \mathrm{~kg} / \mathrm{ha} / \text { day }) \text { were also recorded } \\
\text { under Rhizobium }+\mathrm{PSB}+60 \mathrm{~kg} \mathrm{P}_{2} \mathrm{O}_{5} / \text { ha. Therefore, it is suggested that for achieving } \\
\text { sustainable higher production and productivity of mungbean should be fertilized with } \\
\text { Rhizobium }+\mathrm{PSB}+60 \mathrm{~kg} \mathrm{P}_{2} \mathrm{O}_{5} / \mathrm{ha} \text {. }\end{array}$ \\
\hline
\end{tabular}

\section{Introduction}

Mungbean (Vigna radiata L.) is widely cultivated throughout southern Asia including India, Pakistan, Bangladesh, Sri Lanka, Thailand, Laos Taiwan south china and Malaysia in India, mungbean is cultivated in all the three seasons, that is kharif, rabi and zaid. It is one of the important pulse crops cultivated in India ranking third having about $70 \%$ of the world area and $45 \%$ of production. Mungbean is mostly grown in the state of Rajasthan (30.81\%), Maharashtra (19.51\%), Karnataka (15.35\%), Andhra Pradesh (12.79\%), Orissa (7.41\%), Tamil Nadu $(4.97 \%)$, and Uttar Pradesh $(2.09 \%)$. In India area occupied by mungbean is about $3.0 \mathrm{~m}$ ha with total production of 1.1 million tones but average productivity is $3.20(\mathrm{q} / \mathrm{ha})$. It is one of the worth of crops rich in protein. Mungbean seeds are rich in protein that is used completed, split peas or flour. Compare with the varieties mungbean very easily digestible, palatable and tastier. Its seed for produce soup, seasoned rice is used. During summer, it can also be used as a green manure crop. Being a leguminous crop, it has the capacity to fix atmospheric nitrogen. Its green plants are used as fodder after removing the mature pods (Kumawat et al., 2009b). The 
yield and nutrition quality of pulses is greatly influenced by application of nutrient elements, organic manures and biofertilizers (Kumawat et al., 2010). The association of Rhizobium and pulse plants helps in improving fertility of soil and is a cost effective method of nitrogen fertilization in legumes (Meena et al., 2014). The amount of nitrogen fixed varies with the strain of Rhizobium, the plant species and environmental conditions. Because of nitrogen fixation legumes are self-dependent for their $\mathrm{N}$ requirement and play a significant role in maintaining the nitrogen balance in the soil. They also improve both physical properties such as soil aggregate stability, bulk density and biological properties of soil (Bahadur and Tiwari, 2014).

Application of nitrogen in combination with phosphorus to mungbean also increases its yield and yield components while nitrogen uptake and protein content of mungbean increase with increasing rate of applied phosphorus. Phosphorus is an essential constituent of nucleic acids and stimulates root growth as well as increase nodule activity in plant. Thus increase the mungbean yield and improves its quality (Malik et al., 2003). Combined inoculation of Rhizobium and PSB not only significantly enhanced the growth characteristics and yield attributes but also resulted significantly higher yield as compared to Rhizobium and PSB inoculation alone because of dual benefit of $\mathrm{N}$ fixation and $\mathrm{P}$ solubilization in greengram (Singh, 1998). Therefore, present study was taken to investigate the effect of nitrogen and biofertilizer on yield attributes and yields of mungbean.

\section{Materials and Methods}

A field experiment was conducted during kharif 2013-14 at Agriculture Research Farm of Institute of Agricultural Sciences,
Bundelkhand University, Jhansi, Uttar Pradesh, which is geographically located at $25^{\circ} .27^{\prime \prime} \mathrm{N}$ latitude and $78^{0} .35 \mathrm{E}$ longitude at an altitude of 271 meters above the mean sea level in semi-arid tract of central India. The soil was sandy loam in texture, neutral in reaction ( $\mathrm{pH} 7.4)$, low in organic carbon $(0.48 \%)$, low available nitrogen $(212.0 \mathrm{~kg} / \mathrm{ha})$, medium available phosphorus $(14.0 \mathrm{~kg}$ $\mathrm{P}_{2} \mathrm{O}_{5} / \mathrm{ha}$ ) and medium in potassium $(185.0 \mathrm{~kg}$ $\mathrm{K}_{2} \mathrm{O} /$ ha) content. The experiment was laid out in randomized complete block design with three replications. The experiment comprised of the eight treatment combinations i.e. control, Rhizobium, PSB, Rhizobium + PSB, Rhizobium + $20 \mathrm{~N} / \mathrm{ha}$, PSB $+60 \mathrm{P}_{2} \mathrm{O}_{5} / \mathrm{ha}$, Rhizobium + PSB + $20 \mathrm{~N} / \mathrm{ha}$ and Rhizobium + $\mathrm{PSB}+60 \mathrm{P}_{2} \mathrm{O}_{5} /$ ha.

The mungbean cv. 'Pant Mung-5' was sown on $30^{\text {th }} \mathrm{July}, 2013$ using seed rate of $25 \mathrm{~kg} / \mathrm{ha}$ with a row spacing of $30 \mathrm{~cm}$. The crop was harvested on $08^{\text {th }}$ October, 2013. Seed treated with thiram @ $2.5 \mathrm{~g} / \mathrm{kg}$ seed and inoculated as per technical programme were sown in furrows behind small hand driven country plough. Just after sowing, furrows in each plot were covered with soil by manual labour while at complete sowing; planking was done on whole experimental area.

The nodules/plant was taken at flowering stage. Uproot plants and put in a bucket filled with water and roots were washed. After proper washing of roots, nodules were counted separately for each plant root. Figures of all the five plant were added together and sum was divided by five to get the average number of root nodules/plant.

Fully mature and develop pods from randomly selected five plants from each plot were plucked and number of seeds were counted. The average number of pods and seeds/plants was worked out. After threshing and winnowing the weight of seeds for each 
net plot area was recorded in $\mathrm{kg} / \mathrm{plot}$ and then converted to $\mathrm{kg} / \mathrm{ha}$. Production efficiency was calculated as following formula suggested by Kumawat et al., (2015). The data collected were analyzed statistically using analysis of variance techniques (ANOVA) for randomized block design as prescribed by Cocharan and Cox (1957).

Standard error of mean in each case and the critical difference only for significant cases were computed at 5\% levels of probability as under.

\section{Results and Discussion}

Results of the study were revealed that number of nodules/plant, nodules dry weight/plant, yield attributes (number of pods/plant, pod length, number of seeds/pod, seed yield/plant and test weight) and seed and straw yield of mungbean (Table 1). Results showed marked variation due to application of fertilizers and biofertilizers as compared to control.

Higher number of nodules (25.10) and dry weight of nodules/plant $(24.10 \mathrm{mg})$ was recorded in Rhizobium $+\mathrm{PSB}+20 \mathrm{~kg} \mathrm{~N} / \mathrm{ha}$ which was statistically at par with Rhizobium + PSB + $60 \mathrm{~kg} \mathrm{P}_{2} \mathrm{O}_{5} /$ ha and Rhizobium + PSB and significantly superior to rest of treatments.

This could be attributed to combined application of nitrogen, phosphorus and bioferilizers has play vital functions such as utilization of sugar and starch cell division, photosynthesis and root growth.

Also, spreading root system gives more size for infection by Rhizobium and increases their proliferation in rhizosphere, thus help in formation of higher number of as well as better size of nodules, thereby increasing dry weight of root nodules which is in accordance with that of Kumawat et al., (2009c), Singh et al., (2013). Further data showed that yield attributes viz., number of pods/plant, pod length, number of seeds/pod, seed yield/plant and test weight as influenced by chemical fertilizers and biofertilizers. Maximum pods/plant (70.48) was recorded in the fertilized plot Rhizobium + PSB $+60 \mathrm{~kg}$ $\mathrm{P}_{2} \mathrm{O}_{5} /$ ha which as at par to each other and significantly superior to control and alone seed inoculation of Rhizobium + PSB. Similarly higher pod length $(5.78 \mathrm{~cm})$ was noted under Rhizobium + PSB + $60 \mathrm{~kg}$ $\mathrm{P}_{2} \mathrm{O}_{5} /$ ha and significantly superior over rest of the treatments. Maximum seeds/pod (8.63) was also recorded with the application of Rhizobium + PSB + $60 \mathrm{~kg} \mathrm{P}_{2} \mathrm{O}_{5} /$ ha it was statistically similar with Rhizobium + PSB + $20 \mathrm{~kg} \mathrm{~N} / \mathrm{ha}, \mathrm{PSB}+60 \mathrm{~kg} \mathrm{P}_{2} \mathrm{O}_{5} / \mathrm{ha}$ and dual seed inoculation with biofertilizers (Rhizobium + PSB). Further table 1 indicated that highest seed yield (4.58 g/plant) was obtained under application of Rhizobium +

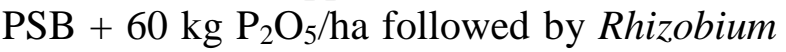
$+\mathrm{PSB}+20 \mathrm{~kg} \mathrm{~N} / \mathrm{ha}$ and PSB+60 kg $\mathrm{P}_{2} \mathrm{O}_{5} / \mathrm{ha}$ which was statistically at par to each other's.

Highest test weight (40.05 g) was obtained from the plot fertilized with Rhizobium + PSB $+60 \mathrm{~kg} \mathrm{P}_{2} \mathrm{O}_{5} / \mathrm{ha}$ which was similar to Rhizobium + PSB, Rhizobium + $20 \mathrm{~kg} \mathrm{~N} / \mathrm{ha}$, $\mathrm{PSB}+60 \mathrm{~kg} \mathrm{P}_{2} \mathrm{O}_{5} / \mathrm{ha}$ and Rhizobium $+\mathrm{PSB}+$ $20 \mathrm{~kg} \mathrm{~N} / \mathrm{ha}$.

The increase in yield attributes due to inoculation with dual (Rhizobium + PSB) might be due to production of growth promoting substances such as auxins, gibberellins and cytokines which might improve plant growth and stimulate the microbial development. The cumulative effect might be due to supply of nitrogen and phosphorus to the crop and also increased solubilization of mineral phosphates and other nutrients similar observation was recorded by Tanwar, (1997), Kumar et al., (2010) and Kumar and Kumawat (2014). 
Table.1 Effect of nutrition management on nodulation, yield attributes and yields of mungbean

\begin{tabular}{|c|c|c|c|c|c|c|c|c|c|c|c|}
\hline Treatments & $\begin{array}{c}\text { No. of } \\
\text { nodules/ } \\
\text { plant }\end{array}$ & $\begin{array}{c}\text { Dry weight of } \\
\text { nodules } \\
\text { (mg/plant) }\end{array}$ & $\begin{array}{l}\text { No. of } \\
\text { pod/ } \\
\text { plant }\end{array}$ & $\begin{array}{c}\text { Pod } \\
\text { length } \\
(\mathrm{cm})\end{array}$ & $\begin{array}{c}\text { No. of } \\
\text { Seeds/ } \\
\text { pod }\end{array}$ & $\begin{array}{c}\text { Seed } \\
\text { yield } \\
\text { /plant }\end{array}$ & $\begin{array}{c}\text { Test } \\
\text { weight } \\
\text { (gm) }\end{array}$ & $\begin{array}{c}\text { Seed } \\
\text { yield } \\
\text { (kg/ha) }\end{array}$ & $\begin{array}{c}\text { Straw } \\
\text { yield } \\
\text { (kg/ha) }\end{array}$ & $\begin{array}{c}\text { Harvest } \\
\text { index } \\
(\%)\end{array}$ & $\begin{array}{c}\text { Production } \\
\text { efficiency } \\
\text { (kg/ha/day) }\end{array}$ \\
\hline Control & 14.02 & 12.06 & 47.08 & 4.75 & 5.95 & 3.32 & 34.08 & 735 & 2135 & 25.61 & 10.35 \\
\hline Rhizobium & 22.04 & 22.10 & 60.88 & 5.48 & 7.65 & 3.75 & 34.10 & 945 & 2258 & 29.50 & 13.31 \\
\hline PSB & 19.07 & 20.08 & 55.42 & 5.45 & 7.09 & 3.89 & 35.11 & 938 & 2303 & 28.94 & 13.21 \\
\hline Rhizobium + PSB & 23.06 & 24.04 & 68.55 & 5.65 & 8.08 & 3.92 & 37.09 & 1088 & 2510 & 30.24 & 15.32 \\
\hline Rhizobium $+\mathbf{N}_{20}$ & 21.10 & 22.04 & 64.80 & 5.55 & 7.09 & 4.12 & 36.48 & 968 & 2368 & 29.02 & 13.63 \\
\hline $\mathbf{P S B}+\mathbf{P}_{60}$ & 22.04 & 21.08 & 66.55 & 5.07 & 8.05 & 4.18 & 36.58 & 1006 & 2428 & 29.30 & 14.17 \\
\hline Rhizobium $+\mathrm{PSB}+\mathrm{N}_{20}$ & 25.10 & 24.10 & 69.35 & 5.68 & 8.03 & 4.30 & 38.09 & 1095 & 2606 & 29.59 & 15.42 \\
\hline Rhizobium $+\mathrm{PSB}+\mathrm{P}_{60}$ & 25.08 & 24.04 & 70.48 & 5.78 & 8.68 & 4.58 & 40.05 & 1235 & 2507 & 33.00 & 17.39 \\
\hline SEm \pm & 0.75 & 0.89 & 1.56 & 0.16 & 0.23 & 0.17 & 1.27 & 28 & 186 & 0.90 & 0.44 \\
\hline CD at $5 \%$ & 2.62 & 2.71 & 4.70 & 0.47 & 0.68 & 0.49 & 3.75 & 86 & 563 & 2.72 & 1.34 \\
\hline
\end{tabular}


Varying treatments of nutrient management has significant effect on the seed yield, straw yield and harvest index of mungbean (Table $1)$. The highest seed yield (1235 kg/ha) was obtained in Rhizobium + PSB $+60 \mathrm{~kg} \mathrm{P}_{2} \mathrm{O}_{5} / \mathrm{ha}$ which was significantly superior over rest of the treatments. Similarly the maximum straw yield (2507 kg/ha) was also noted under Rhizobium + PSB + $60 \mathrm{~kg} \mathrm{P}_{2} \mathrm{O}_{5} / \mathrm{ha}$ and this treatment statistically at par to all the treatments except control and Rhizobium alone. The data regarding harvest index and production efficiency as affected by various treatments. Dual seed inoculation along with $60 \mathrm{~kg} \mathrm{P}_{2} \mathrm{O}_{5} /$ ha gave maximum harvest index $(33.0 \%)$ and production efficiency (17.39 $\mathrm{kg} / \mathrm{ha} /$ day) which was significantly superior to rest of the treatments. The enhanced nodulation and improved nitrogen fixation by plant might have also increased the seed yield due to the better nutritional environment during crop period. Due to the phosphorus supplying might have stimulated at the rate of various physiological process favouring increased growth and yield attributes and finally the yield. Thus, it appears that the increase in seed yield owing to application of phosphorus was resulted of cumulative effect of improved growth and yield attributes. This results obtained are in close conformity with those of Moolani et al., (2006), Kumawat et al., (2009a), Panwar et al., (2012) and Bhanwariya et al., (2013).

\section{References}

Bahadur, L. and Tiwari, D.D. 2014. Nutrient management in mung bean (Vigna radiata L.) through sulphur and biofertilizers. Legu. Res., 37 (2): 180187.

Bhanwariya, B., Ram, M., Kumawat, N., Kumar, R. 2013. Influence of fetilizer levels and biofertilizers on growth and yield of Linseed (Linum usitatissimum L.) under rainfed condition of south
Gujarat. Madras Agric. J., 100 (4-6): 403-406.

Cocharan, W.G. and Cox, G.M. 1957. 'Experimental Design" Second Edition, Wiley, N.Y.

Kumar, A., Singh, S.S., Kumar, R., Singh, A.K., Kumawat, N. 2010. Response of Rhizobium and different levels of molybdenum on growth, nodulation and yield of blackgram (Vigna mungo L.). Environ. Ecol., 28 (3A): 1728-1730.

Kumar, R. and Kumawat, N. 2014. Effect of sowing dates, seed rates and integrated nutrition on productivity, profitability and nutrient uptake of summer mungbean in Eastern Himalaya. Archi. Agron. Soil Sci., 60 (9): 1207-1227.

Kumawat, N., Kumar, R. and Sharma, O.P. 2009a. Nutrient uptake and yield of mungbean [Vigna radiata (L.) Wilczek] as influenced by organic manures, PSB and phosphorus fertilization. Environ. Ecol., 27 (4B): 2002-2005.

Kumawat, N., Sharma, O.P. and Kumar, R. 2009b. Effect of organic manures, PSB and phosphorus fertilization on yield and economics of mungbean [Vigna radiata (L.) Wilczek]. Environ. Ecol., 27 (1): 5-7.

Kumawat, N., Sharma, O.P., Kumar, R. and Kumari, A. 2009c. Response of organic manures, PSB and phosphorus fertilization on growth and yield of mungbean. Environ. Ecol., 27 (4B): 2024-2027.

Kumawat, N., Sharma, O.P., Kumar, R. and Kumari, A. 2010. Yield and yield attributes of mungbean [Vigna radiata (L.) Wilczek] as affected by organic manures, PSB and phosphorus fertilization. Environ. Ecol., 28 (1A): 332-335.

Kumawat, N., Singh, R.P., Kumar, R., Yadav, T.P. and Hari, Om. 2015. Effect of integrated nutrient management on productivity, nutrient uptake and 
economics of rainfed pigeonpea (Cajanus cajan) and blackgram (Vigna mungo) intercropping system. Indian $J$. Agric. Sci. 85: 171-176.

Malik, M.A., Saleem, M.F., Ali, A. and Mahmood, I. 2014. Effect of nitrogen and phosphorus application on growth yield and quality of mungbean (Vigna radiata L.). Pak. J. Agri. Sci., 40 (3-4): 133-136.

Meena, J.S., Verma, H.P. and Pincholi, P. 2014. Effect of fertility levels and biofertilizers on yield, quality and economic of cowpea. Agric. Sust. Develop, 2(2):162-164.

Moolani, M.K. 2006. Effect of N-P fertilization on growth and yield of gram. Ann. Arid Zone, 5: 127-33.

Panwar, K.S. Pandey, K. and Singh, M. 2012. Response of some promising varieties of mung to levels of phosphorus. Indian J. Agron., 23: 366-367.

Singh, A.K., Choudhary, R.K. and Roy Sharma, R.P. 2013. Effect of inoculation and fertilizer levels on yield, yield attributes and nutrient uptake of greengram (Phaseolus radiatus) and blackgram (Phaselous mungo). Indian J. Agron., 38(4): 663-65.

Singh, M. 1998. Efficiency of biofertilizers and weed control methods on productivity of greengram [Vigna radiata L. Wilczek]. M.Sc. (Ag) Thesis, Raj. Agril. Univ., Bikaner.

Tanwar, S.P.S. 1997. Effect of phosphorus and biofertilizers on growth and productivity of blackgram (Vigna mungo L. Helper). M.Sc. (Ag) Thesis, Raj. Agril. Univ. Bikaner.

\section{How to cite this article:}

Ghanshyam Verma, Narendra Kumawat and Jagdeesh Morya. 2017. Nutrient Management in Mungbean [Vigna radiata (L.) Wilczek] for Higher Production and Productivity under Semiarid Tract of Central India. Int.J.Curr.Microbiol.App.Sci. 6(7): 488-493. doi: https://doi.org/10.20546/ijcmas.2017.607.058 